\title{
Seasonal and regional variations in plankton community production and respiration for Chesapeake Bay
}

\author{
Erik M. Smith, W. Michael Kemp \\ University of Maryland System, Center for Environmental and Estuarine Studies, Horn Point Environmental Laboratory, \\ Cambridge, Maryland 21613, USA
}

\begin{abstract}
Plankton community production and respiration rates were examined at 3 stations representing distinct regions along the estuarine gradient in the main stem of Chesapeake Bay, USA. Rates were measured as in vitro changes in oxygen concentration, as determined by Winkler titration with an automated photometric end-point detection system. At each station rates of both processes exhibited annual patterns which followed that of water temperature. There were distinct differences, however, among the 3 stations in the relative magnitude of metabolic rates measured. Annual rates of daytime net plankton community production were estimated to be 265,1680 , and $2040 \mathrm{~g} \mathrm{O}_{2} \mathrm{~m}^{-2} \mathrm{yr}^{-1}$, while annual night-time plankton community respiration rates in the upper water column were estimated as 130, 1090, and $490 \mathrm{~g} \mathrm{O}_{2} \mathrm{~m}^{-2} \mathrm{yr}^{-1}$ at the upper, middle and lower Bay stations, respectively. Thus, whereas rates of net daytime production increased substantially moving downbay, highest measured rates of community respiration were, in fact, found in the middle region of the Bay. Annual cycles of production and respiration rates were significantly related to each other at the upper and middle stations, but unrelated at the lower station. Integrated estimates of net plankton community metabolism (production minus respiration) at the 3 stations exhibited seasonal patterns departing from balanced metabolism (production $=$ respiration) during winter - spring and converging on zero net metabolism in summer-fall. During the cooler months net plankton metabolism was negative (net heterotrophic) at the upper station and positive (net autotrophic) at the middle and lower stations. Over the annual cycle, the 3 stations showed a longitudinal pattern of increasing diel net plankton community metabolism, progressing from a net heterotrophy of $-70 \mathrm{~g} \mathrm{O}_{2} \mathrm{~m}^{-2} \mathrm{yr}^{-1}$ in the turbid, upper Bay, to slightly positive metabolism of $160 \mathrm{~g} \mathrm{O}_{2} \mathrm{~m}^{-2} \mathrm{yr}^{-1}$ in the mid-region, to strong net autotrophy of $760 \mathrm{~g} \mathrm{O}_{2} \mathrm{~m}^{-2} \mathrm{yr}^{-1}$ in the less turbid, lower Bay.
\end{abstract}

KEY WORDS: Plankton · Production · Respiration · Net community metabolism · Oxygen · Chesapeake Bay

\section{INTRODUCTION}

Primary production of planktonic communities represents a critical link between inputs of new nutrients and production of fish in estuaries and other aquatic ecosystems (e.g. Nixon et al. 1986, Iverson 1990). The proportion of phytoplankton production which is available for transfer to higher trophic levels depends in part, however, on the degree of coupling between autotrophic production (P) and heterotrophic respiration $(\mathrm{R})$ within the plankton community. Although $\mathrm{P}$ and $\mathrm{R}$ tend to converge at large scales, physical and biological interactions within a given environment, or between adjacent systems, often cause the 2 processes to be separated in time or space (Williams 1984). In general, most biogeochemical cycles are driven by the flux of organic matter which accompanies the uncoupling of photosynthesis and respiration (Geider 1992). Consequently, it is the net ( $\mathrm{P}$ minus $\mathrm{R}$ ) rather than total $(\mathrm{P})$ production of the planktonic community that defines the amount of organic matter available for export to the benthos or to adjacent ecosystems or for transfer to higher pelagic trophic levels. 
Over the last several decades, research on plankton community production has tended to focus on measurement of phytoplankton photosynthesis, particularly since the introduction of the ${ }^{14} \mathrm{C}$ technique (SteemannNielsen 1952). Associated with this trend was the general loss of favor for use of oxygen $\left(\mathrm{O}_{2}\right)$ as a tracer of metabolic rates (as employed by e.g. Gaarder \& Gran 1927, Ryther 1954), due in part to the ease and precision of the ${ }^{14} \mathrm{C}$ method (Peterson 1980). As a result there has been a relatively limited availability of direct measures of planktonic respiration (Williams 1984) and a tendency to equate phytoplankton photosynthesis with net production for whole plankton communities (Nixon \& Pilson 1984). Recent technological advances in $\mathrm{O}_{2}$ measurements using automated versions of the traditional Winkler titration (e.g. Hartwig \& Michael 1978, Williams \& Jenkinson 1982, Oudot et al. 1988), improved electrode sensors (e.g. Griffith 1988, Langdon 1984 ) and ${ }^{18} \mathrm{O}$ isotopic techniques (e.g. Bender \& Grande 1987, Kana 1990) have resulted in a renewed interest in oxygen as a suitably sensitive tracer for the measurement of both respiration and production of planktonic communities.

Several previous studies have reported rates of plankton oxygen production and respiration in Chesapeake Bay (e.g. Kemp \& Boynton 1980, Taft et al. 1980, Tuttle et al. 1987, Kemp et al. 1992), but these have been for limited sites and/or seasons. In the present paper we describe annual cycles of plankton community production and respiration for 3 main regions of this estuary, and consider the relationship between these 2 metabolic processes. We also examine how the balance between plankton production and respiration varies between seasons and stations, as well as the ecological implications of these variations.

\section{MATERIALS AND METHODS}

Sample locations and frequency. Three stations ('Upper Bay', UB: $39^{\circ} 20.9^{\prime} \mathrm{N}$, $76^{\circ} 10.9^{\prime} \mathrm{W}$; 'Mid Bay', MB: $38^{\circ} 28.4^{\prime} \mathrm{N}$, $76^{\circ} 22.8^{\prime} \mathrm{W}$; 'Lower Bay', LB: $37^{\circ} 16.1^{\prime} \mathrm{N}$, $76^{\circ} 09.0^{\prime} \mathrm{W}$ ) along the main axis of the Chesapeake Bay (Fig. 1) were occupied at approximately 2 mo intervals from April to November in 1989 and 1990 and at monthly intervals from Februar to November in 1991. On several occasions, however, data for specific stations were not collected due to logistical difficulties involving equipment or weather. Additionally, during 1989 and
1990, 18 stations along the vertical axis of the main channel were sampled for vertical profiles of salinity, temperature and light penetration (as measured by Secchi disk depth). Nominal water column depths at the 3 main stations ranged from 6 to 8,18 to 23 , and 10 to $12 \mathrm{~m}$ at the UB, MB and LB stations, respectively. Water samples at these stations were obtained from surface ( $2 \mathrm{~m}$ below air-sea interface) and bottom layers ( $2 \mathrm{~m}$ above sediment-water interface) at each station during morning (07:00 to 10:00 h) using an array of Niskin bottles (20 l) mounted on a CTD (Neil Brown Instruments), which provided concurrent vertical profiles of temperature, salinity, oxygen and in situ fluorescence. Immediately after completion of the hydrocast, water was gently combined from several Niskin bottles into low-density polyethylene (Nalgen) carboys (50 1) to ensure homogeneity in the sample. Water was then siphoned into standard, clear, acidwashed, glass BOD incubation bottles $(300 \mathrm{ml})$, which were flushed, filled, and capped with ground glass stoppers.

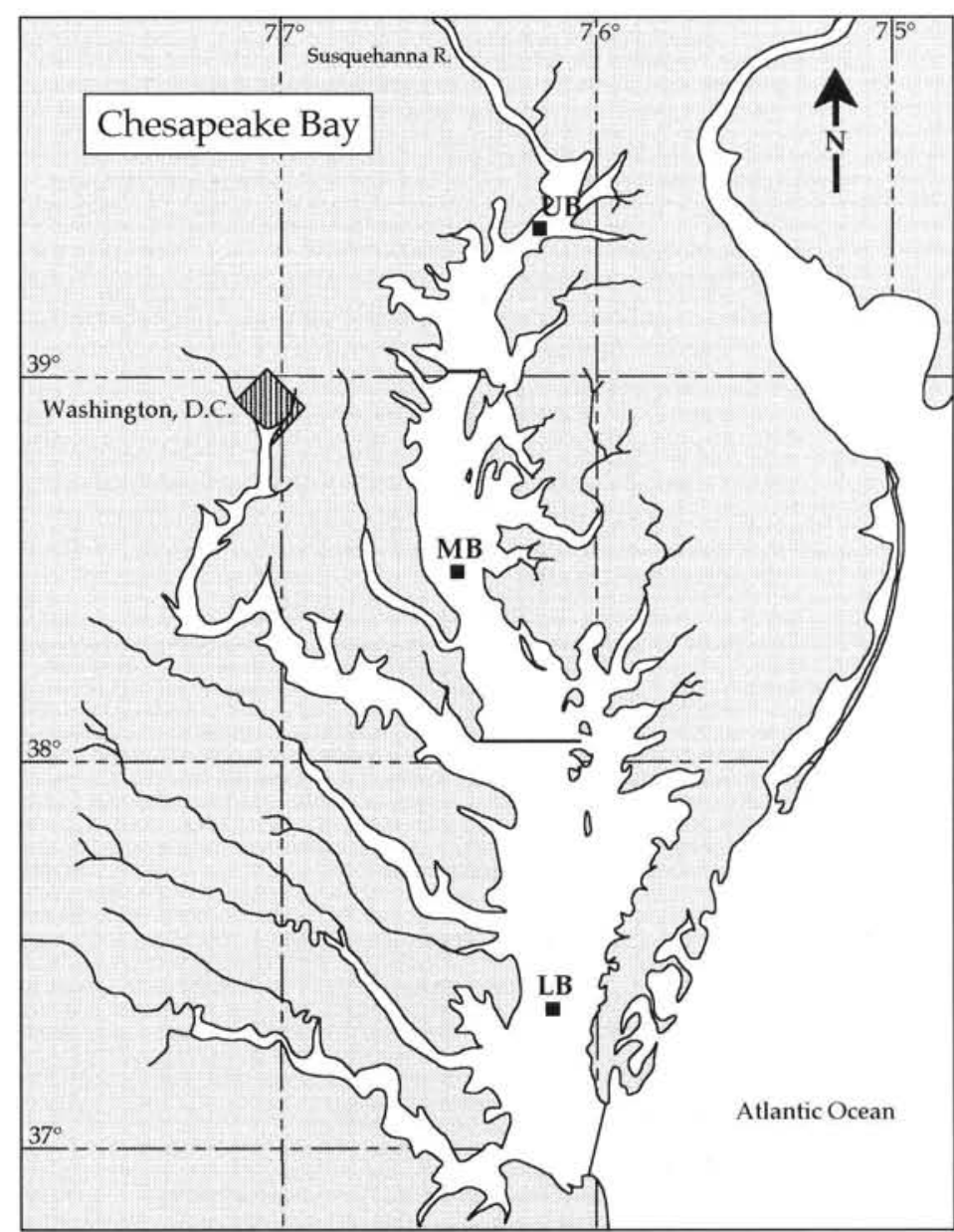

Fig. 1. Chesapeake Bay, USA, with 3 stations along the axis of the main stem. Solid lines indicate divisions between Bay regions used in Table 3 
Production and respiration rate measurements. Net planktonic community production and respiration rates were measured as changes in dissolved oxygen in replicate clear and opaque incubation bottles (Kemp et al. 1992). All oxygen concentrations were determined by Winkler titration of whole samples in the incubation bottles (Carritt \& Carpenter 1966), with visual end-point detection in 1989 and by a computercontrolled, photometric detector system (Sensoren Instrumente Systeme, Kiel, Germany) in subsequent years. This automated titration system had a minimum precision of $0.01 \%$.

Plankton production was measured using duplicate clear BOD bottles containing surface water incubated for 4 to $5 \mathrm{~h}$ at in situ temperatures $\left( \pm 1^{\circ} \mathrm{C}\right)$, in an incubator equipped with high-output, cool-white fluorescent lamps, at each of 5 irradiance levels (ca 25, 30, $65,130,250,450 \mu$ Ein $\mathrm{m}^{-2} \mathrm{~s}^{-1}$ ) using neutral-density screening of individual bottles (e.g. Harding et al. 1986). Ambient incident photosynthetically active radiation (PAR, 400 to $700 \mathrm{~nm}$ ) was measured on shipboard for the day of each rate measurement using an integrating PAR sensor (Licor model L1-1000). Light reaching each bottle was expressed as a percentage of mean integrated ambient PAR $\left(\mu \operatorname{Ein} \mathrm{m}^{-2} \mathrm{~s}^{-1}\right)$ for the day of incubation.

Production of oxygen at each light level was normalized to measured in situ chlorophyll a (chl a) concentrations. Chl a was extracted from fresh particulate material collected by filtration (Whatman GF/F glass fiber filters, $1.2 \mu \mathrm{m})$ with aqueous acetone $(90 \%)$ and quantified fluorometrically before and after acidification (Parsons et al. 1984) with a Turner Fluorometer. The chlorophyll-specific production $\left(P^{\mathrm{B}}\right)$ versus irradiance $(I)$ relationship was modeled as the nonlinear hyperbolic tangent function (Jassby \& Platt 1976):

$$
P^{\mathrm{B}}=P_{\mathrm{m}}^{\mathrm{B}} \tanh \left(\frac{\alpha I}{P_{\mathrm{m}}^{\mathrm{B}}}\right)+R^{\mathrm{B}}
$$

where $\alpha\left[\mathrm{mg} \mathrm{O}_{2} \mathrm{mg}^{-1} \mathrm{chl}\right.$ a $\left.\left(\mu \text { Ein } \mathrm{m}^{-2} \mathrm{~h}^{-1}\right)^{-1}\right]$ is the initial slope of the light-saturation curve, $P_{\mathrm{m}}^{\mathrm{B}}\left(\mathrm{mg} \mathrm{O}_{2}\right.$ $\mathrm{mg}^{-1} \mathrm{chl} \mathrm{a} \mathrm{h}^{-1}$ ) is the light-saturated biomass-specific production rate, and $R^{\mathrm{B}}$ is the biomass-specific respiration rate. Values of $\alpha$ and $P_{\mathrm{m}}^{\mathrm{B}}$ that best described each data set were estimated by least-squares fit (Marquardt 1963). Once the specific relationship for $P^{\mathrm{B}}$ versus $I$ was determined, community production $\left(\mathrm{g} \mathrm{O}_{2} \mathrm{~m}^{-2}\right.$ $\mathrm{h}^{-1}$ ) was integrated over the depth of the euphotic zone (to $1 \%$ surface irradiance) based on vertical attenuation of light (from Secchi disk depth) and chl a distributions (cf. Malone et al. 1988). Integrated rates of net community production ( $\mathrm{g} \mathrm{O}_{2} \mathrm{~m}^{-2} \mathrm{~d}^{-1}$ ) were then calculated as hourly production rates multiplied by hours of the day in which incident PAR exceeded $100 \mu$ Ein $\mathrm{m}^{-2}$ $\mathrm{s}^{-1}$. This value is referred to as daytime net plankton community production $\left(P_{\mathrm{n}}\right)$.

Dark respiration rates were measured as decreases in oxygen concentration in replicate (4 or 5) bottles containing surface or bottom water samples. Bottles were incubated in removable opaque sleeves, at in situ temperatures $\left( \pm 1^{\circ} \mathrm{C}\right.$ ) for 4 to $12 \mathrm{~h}$, with 5 bottles of both surface and bottom water initially fixed for Winkler titrations. Vertically integrated areal $\left(\mathrm{m}^{-2}\right)$ rates for the upper layer were calculated as the product of volumetric $\left(\mathrm{m}^{-3}\right)$ rates and the mean depth to the pycnocline. Integrated areal rates for the lower layer were obtained by multiplying volumetric rates by the average height of the lower layer water column, estimated from hypsographic information of the Bay cross-section at each station (Cronin \& Pritchard 1975). This integration for the lower layer accounted for the relative reduction in volume in the lower layer with increasing depth of the pycnocline, due to the triangular shape of the main channel (Kemp et al. 1992).

Net community metabolism calculations. Conceptual framework: To compare the relative balance between the processes of phytoplankton production and plankton community respiration on an areal basis, discrete volumetric respiration rates had to be depthintegrated to obtain units comparable to that of net community production $\left(\mathrm{g} \mathrm{O}_{2} \mathrm{~m}^{-2} \mathrm{~d}^{-1}\right)$. In this regard, the vertical structure of the water column at each station, as well as the stations' mean vertical dimensions, become important factors in the calculation. The 3 stations sampled in this study exhibited distinct differences in overall depth and the nature of their vertical structure (Fig. 2). For purposes of integration, the structure of the water column at the 3 stations was partitioned into 2 distinct layers, each assumed to be vertically mixed, based on vertical profiles of salinity and temperature.

Overall, annual mean values of pycnocline depth (estimated as the point of maximum salinity and/or temperature change) and depth of the euphotic zone (as $1 \%$ light penetration) tended to track each other remarkably well (Wofsy 1983) along the entire axis of the bay (Fig. 2), suggesting a logical depth division for the water column integration. There were, however, some important differences among the stations. At the UB station, there was often no discernible vertical structure to the water column, in which case the upper mixed layer was taken to be the depth of the euphotic zone. At the MB station, the depth of the euphotic zone was consistently at or just slightly above the determined pycnocline depth. The situation was, however, reversed at the LB station. Here, although the depth of $1 \%$ light penetration was comparable to that found at $\mathrm{MB}$, the pycnocline depth was more variable and would occasionally shoal above the euphotic depth, enough such that the 


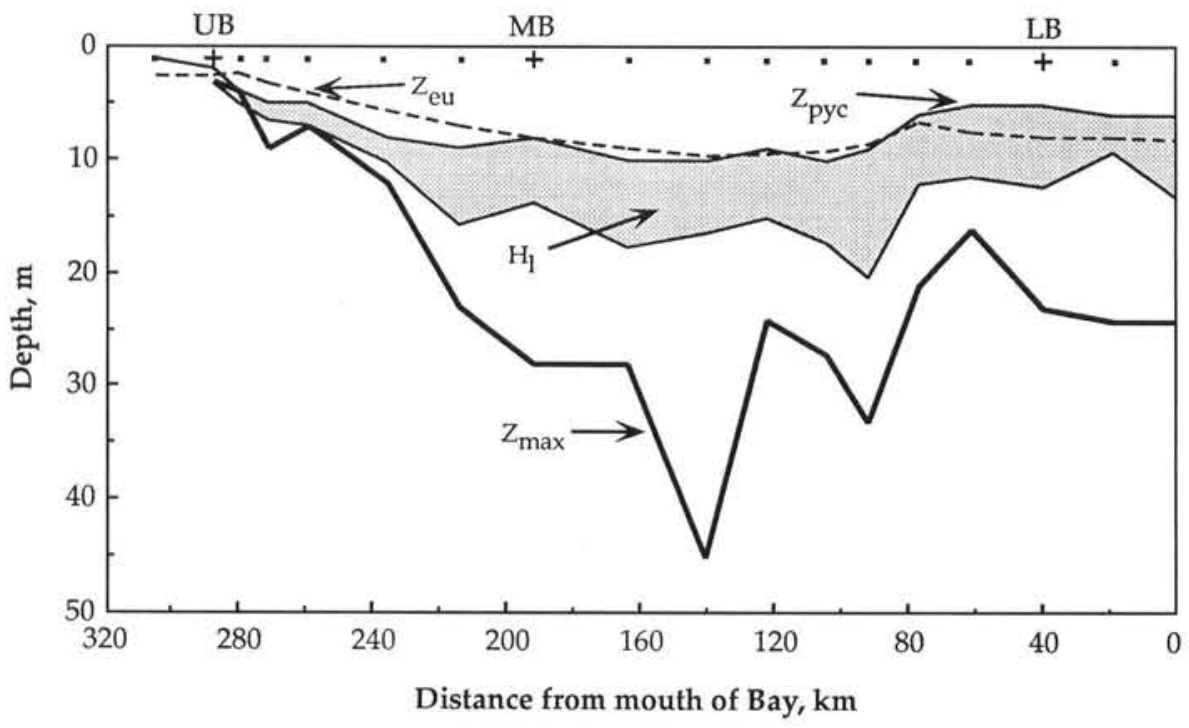

Fig. 2. Longitudinal section of main-stem Chesapeake Bay showing annual mean depths of the euphotic zone $\left(Z_{\mathrm{eu}}\right)$, pycnocline $\left(Z_{\text {pyc }}\right)$, and maximum channel depth $\left(Z_{\max }\right)$. The width of the shaded area $\left(\mathrm{H}_{\mathrm{l}}\right)$ bounded at the top by $Z_{\text {pyc }}$ represents the mean height of the lower layer of the water column (see text for explanation of calculation). Plankton metabolism stations (+) and longitudinal mapping stations (*) are indicated at the top of the figure. (Light data from Kemp et al. unpubl., hypsographic data from Cronin \& Pritchard 1975) annual mean depth of the euphotic zone exceeded the mean of the pycnocline. At this station, the observed strength of the pycnocline was also typically much less than that seen at MB, thus allowing for the possibility of increased mixing between layers. As a result, when this situation occurred, the base of the euphotic zone was used as the boundary of the upper layer, to be conservative in calculating integrated aphotic respiration rate. In the single most extreme case, however, the resulting difference was on the order of $15 \%$.

The appropriate height of the lower mixed layer was somewhat more problematic due to the irregular nature of the bottom topography in the main channel of the Bay. To obtain a representative mean height of the lower layer at each of the 3 stations, cross-sectional hypsographic data from Cronin \& Pritchard (1975) were used to calculate the average cross-sectional channel depth lying below the given depth of the pycnocline (Fig. 2), the difference in depths being the mean height of the lower layer (Fig. 2 shaded area; Kemp et al. 1992). It can be seen there were dramatic differences between the maximum depth of the channel and its mean depth for large portions of the Bay. Thus, the vertical dimension of the lower layer becomes important in the integration of lower layer respiration rates. This integration applies only to the plankton community metabolism of the main channel (where water column depth exceeds euphotic depth). Because of differences in vertical dimensions, integrated plankton community metabolism over the shallow flank regions could have a differing metabolic balance, so that the focus of this paper is restricted to the main channel region. Based on hypsographic data from Cronin \& Pritchard (1975), this main channel region represents approximately $52 \%$ of the total Bay surface area but $76 \%$ of the total Bay volume.
Diel rates of net metabolism of the planktonic community were calculated for both the upper mixed layer $\left(N P M_{\mathrm{u}}\right)$ and for the entire water column (NPM). NPM was calculated as daytime net community production $\left(P_{\mathrm{n}}, \mathrm{g} \mathrm{O}_{2} \mathrm{~m}^{-2} \mathrm{~d}^{-1}\right)$ minus nighttime respiration in the upper layer $\left(R_{\mathrm{u}}, \mathrm{g} \mathrm{O}_{2} \mathrm{~m}^{-2} \mathrm{~d}^{-1}\right)$. Nighttime respiration for the upper layer is the vertically integrated hourly rate multiplied by the hours of darkness. Thus, $N P M_{\mathrm{u}}$ is the net diel plankton community production of the upper layer. NPM represents the net diel plankton metabolism of the entire water column and is therefore equal to $N P M_{\mathrm{u}}$ minus the respiration in the aphotic lower layer $\left(R_{1}, \mathrm{~g} \mathrm{O}_{2} \mathrm{~m}^{-2} \mathrm{~d}^{-1}\right)$, which is calculated as the depth-integrated lower layer hourly rate multiplied by $24 \mathrm{~h}$. Ratios of production:respiration were calculated for the upper layer as $P_{\mathrm{n}}: R_{\mathrm{u}}$ and for the entire water column as $P_{\mathrm{n}}:\left(R_{\mathrm{u}}+R_{1}\right)$.

For the MB station during summer, when the bottom waters were anoxic, vertical profiles revealed that waters between 1 and $5 \mathrm{~m}$ below the pycnocline still contained some oxygen. Therefore, when estimating NPM during these time periods, $R_{1}$ was calculated for a water column of variable height, based on the thickness of the oxygenated layer (down to approximately $0.5 \mathrm{mg} \mathrm{O}_{2} \mathrm{I}^{-1}$ ) below the pycnocline. Vertical sampling of respiration rates during this period indicated no significant variations in respiration rates within this layer relative to the upper water column layer.

Error propagation analysis: Calculations of NPM often involve relatively small differences between large numbers, so that it was critical to estimate the errors associated with these means. Because mean rates were based on a series of computations, variances were estimated by error propagation methods using the following model (Bevington 1969). For any function $x=f(u, v)$, the associated variance is 


$$
\sigma_{x}^{2}=\sigma_{u}^{2}\left(\frac{\partial x}{\partial u}\right)^{2}+\sigma_{v}^{2}\left(\frac{\partial x}{\partial v}\right)^{2}+2 \sigma_{u v}^{2}\left(\frac{\partial x}{\partial u}\right)\left(\frac{\partial x}{\partial v}\right)
$$

We assumed that the ratio of variance $\left(\sigma_{u}^{2}, \sigma_{v}^{2}\right)$ to covariance $\left(2 \sigma_{u v}^{2}\right)$ for factors used in this calculation $\left(\alpha, P_{\mathrm{m}}^{\mathrm{B}}, I\right.$, chl $a$, depth, day length) was relatively small, so that the last term in Eq. (2) could be ignored (Bevington 1969). For the hyperbolic tangent function (Eq. 1), with $P_{\mathrm{m}}^{\mathrm{B}}$ and $\left(a / P_{\mathrm{m}}^{\mathrm{B}}\right)$ replaced by $B 0$ and $B 1$, respectively, the propagated error associated with mean values of $P^{\mathrm{B}}$ can be calculated by differentiating Eq. (1) with respect to each of the other variables and substituting into Eq. (2) to obtain the following:

$$
\begin{aligned}
\sigma_{P^{\mathrm{B}}}^{2}= & \sigma_{B O}^{2}\left(\frac{\mathrm{e}^{B ! \cdot l}-\mathrm{e}^{-B 1 \cdot I}}{\mathrm{e}^{B ! \cdot}+\mathrm{e}^{-B 1 \cdot I}}\right)^{2}+\sigma_{B 1}^{2}\left(B O\left(\frac{2}{\mathrm{e}^{B 1 \cdot I}+\mathrm{e}^{-B 1 \cdot}}\right)^{2} I\right) \\
& +\sigma_{R^{B}}^{2}(-1)^{2}+\sigma_{I}^{2}\left(B O\left(\frac{2}{\mathrm{e}^{B ! \cdot}+\mathrm{e}^{-B ! \cdot I}}\right)^{2} B 1\right)^{2}
\end{aligned}
$$

The error for $P^{\mathrm{B}}$ was thus calculated for each incubation light level, and these were integrated by simple linear interpolation to the $1 \%$ irradiance level and then multiplied by day length to produce an error estimate for $P_{\mathrm{n}}$.

\section{RESULTS AND DISCUSSION}

Data were collected during the years 1989 to 1991. When data were separated seasonally by year, mean measured rates for seasonal periods were not significantly different among years (ANOVA, $\mathrm{p}<0.05$ ), either for daytime net community production or community respiration. Data were thus pooled into a single composite year to develop a robust characterization of general seasonal patterns for Chesapeake Bay.

\section{Seasonal and regional variations in production and biomass}

Rates of daytime net community production at the 3 stations followed a clear seasonal cycle, with winter minima and summer maxima (Fig. 3). In general, these seasonal extreme values of $P_{n}$ coincide with annual maximal and minimal temperatures (Fig. 4, upper panels). Although the 3 stations exhibited similar seasonal patterns in the maxima and minima of $P_{\mathrm{n}}$ there were clear longitudinal differences in the seasonal range of measured rates, as well as the relative magnitude of production at the stations. The annual range in $P_{\mathrm{n}}$ values increased markedly in the downbay direction, from 1.8 , to 5.4 , to $10.9 \mathrm{~g} \mathrm{O}_{2} \mathrm{~m}^{-2} \mathrm{~d}^{-1}$, at the $\mathrm{UB}, \mathrm{MB}$, and $\mathrm{LB}$ stations respectively. A similar longitudinal trend is also evident in the magnitude of $P_{\mathrm{n}}$ at

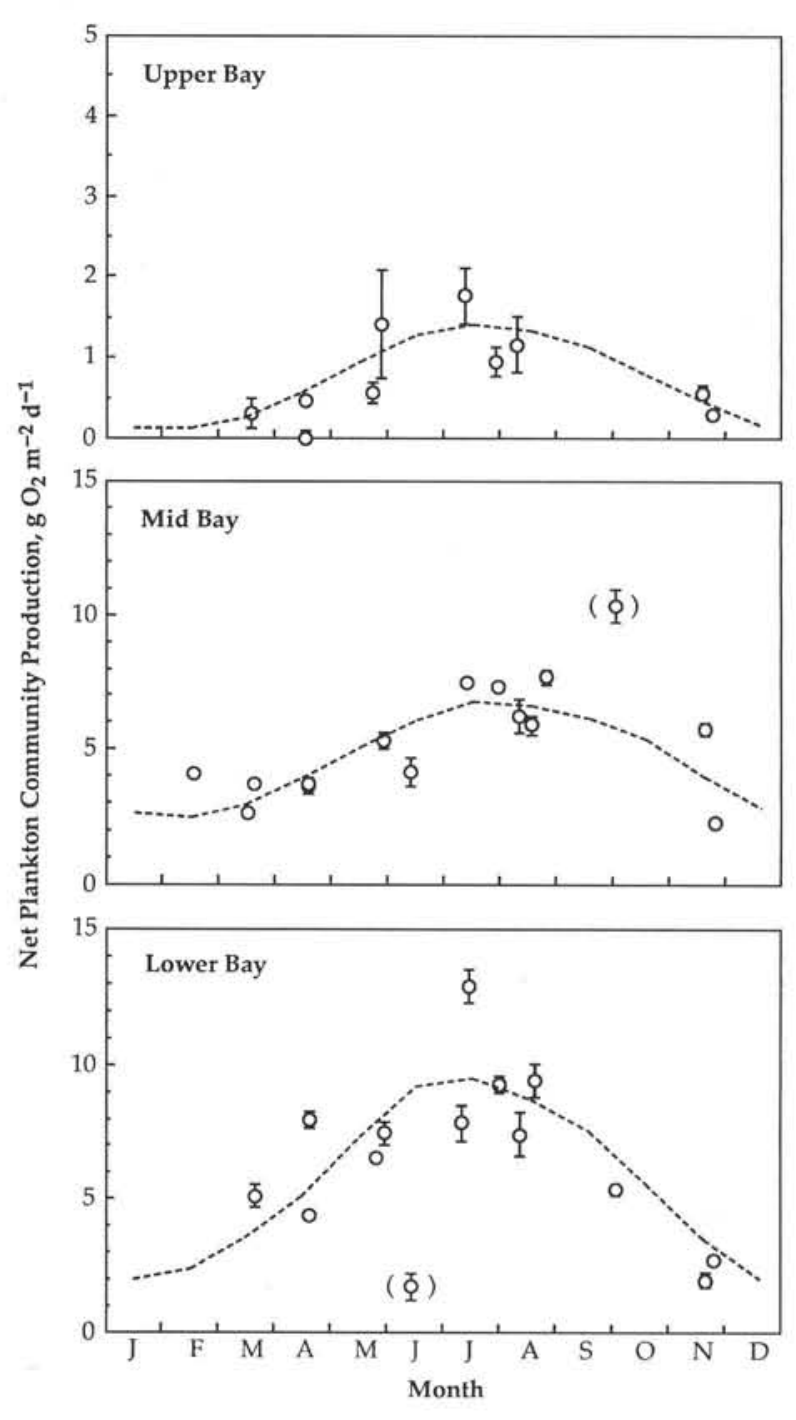

Fig. 3. Seasonal patterns of net community production (with standard errors as calculated from Eq. 3) at the 3 stations, 1989 to 1991 . Dashed lines indicate estimated monthly mean values based on multiple regression equations in Table 1. Data points in parentheses were not included in regression estimates

the 3 stations. Annual mean $P_{\mathrm{n}}$ values increased from $0.8 \pm 0.5 \mathrm{~g} \mathrm{O}_{2} \mathrm{~m}^{-2} \mathrm{~d}^{-1}$ at $\mathrm{UB}$, to $5.4 \pm 2.2 \mathrm{~g} \mathrm{O}_{2} \mathrm{~m}^{-2} \mathrm{~d}^{-1}$ at $\mathrm{MB}$, to $6.5 \pm 3.1 \mathrm{~g} \mathrm{O}_{2} \mathrm{~m}^{-2} \mathrm{~d}^{-1}$ at $\mathrm{LB}$. Thus, on an annual mean basis, there is a substantial, and significant $(\mathrm{p}<0.01)$, increase in daytime net community production values from UB to $\mathrm{MB}$, but a small, and nonsignificant, increase between MB and LB. If, however, one compares peak summer (July-August) rates, there is a significant $(\mathrm{p}<0.01)$ increase in $P_{\mathrm{n}}$ between MB $\left(6.9 \pm 0.8 \mathrm{~g} \mathrm{O}_{2} \mathrm{~m}^{-2} \mathrm{~d}^{-1}\right)$ and $\mathrm{LB}\left(9.4 \pm 2.2 \mathrm{~g} \mathrm{O}_{2} \mathrm{~m}^{-2} \mathrm{~d}^{-1}\right)$. In many temperate estuarine environments, annual cycles of phytoplankton production are characterized by strong seasonality, with peak rates coinciding with the summer temperature maximum (Boynton et al. 

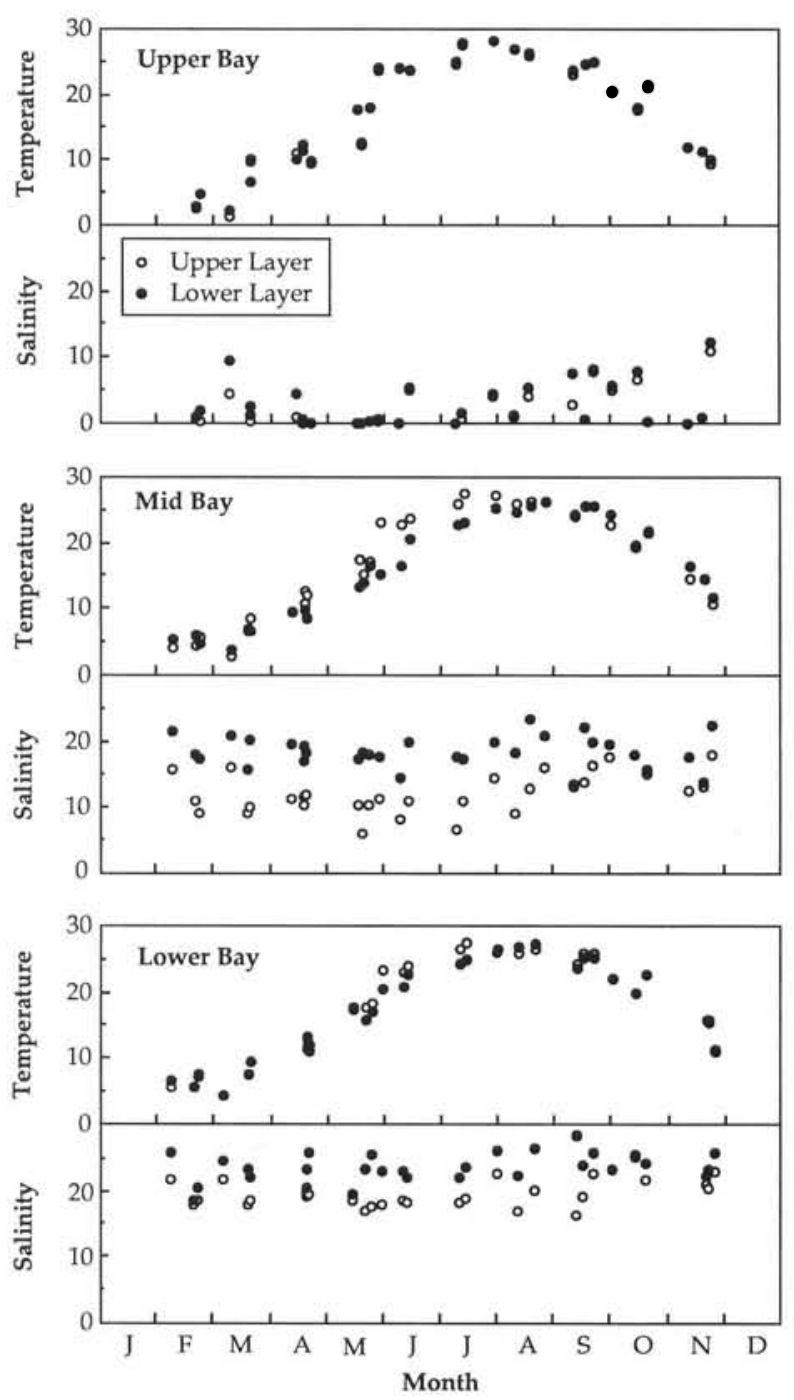

Fig. 4. Seasonal patterns of water temperature $\left({ }^{\circ} \mathrm{C}\right)$ in the upper layer and lower layer, and salinity (\%o) in the upper layer and lower layer, for the 3 stations, 1989 to 1991

1982). Most previous reports for plankton production in the mesohaline region of Chesapeake Bay indicated a seasonal timing in maximal and minimal rates similar to those found in this study (Flemer 1970, Boynton et al. 1982, Malone et al. 1986, 1988). No other studies of Chesapeake Bay have reported annual ranges of production rates for stations distributed over the length of the estuarine gradient.

There were 2 exceptions to the general seasonal pattern observed for production rates at the 3 stations. In September 1991, $P_{\mathrm{n}}$ at the MB station was the highest rate measured for this station (Fig. 3). This high rate coincided with a fall break-down event in the stratification within the mid-Bay region (Fig. 4) which injected high nutrient levels into the nutrient-poor euphotic zone. This event will be considered more fully in a later section. At the LB station, the June (1991) measured rate of $P_{\mathrm{n}}$ dropped substantially from the expected trend (Fig. 3). Within the MB station data there is also a suggestion of a decrease in rates during June, but not of the magnitude seen in the LB station. This late spring period corresponds to the timing of the annual transition from the spring diatom bloom to the summer phytoplankton assemblages dominated by smaller flagellated chlorophytes and dinoflagellates (Sellner 1987, Malone et al. 1988). Although this scenario is based on limited data for June in this study, it is apparent also in previous reports on annual cycles of phytoplankton production in the mesohaline region of Chesapeake Bay (Boynton et al. 1982).

To derive an estimate of annual net community production for the 3 stations, for comparison with published annual rates, a multiple regression model using daily PAR (Ein $\mathrm{m}^{-2} \mathrm{~d}^{-1}$ ) and surface-layer temperature $\left({ }^{\circ} \mathrm{C}\right)$ for each station (Table 1) was used to estimate monthly values of $P_{\mathrm{n}}$ based on mean monthly value of PAR (T. R. Fisher unpubl. data) and temperature (Fig. 4). The observed $P_{\mathrm{n}}$ values were compared with those predicted given the daily PAR and temperature at the time of measurement (Fig. 5a). The precision of the regression estimates was such that $70 \%$ of the predicted values were within $\pm 25 \%$ of the measured values, and $94 \%$ were within $\pm 50 \%$ of those measured. The monthly modeled estimates of $P_{\mathrm{n}}$ are shown in Fig. 3 as a dashed line. From these regression equations we derived annual (365) values of net community production for the period from 1989 to 1991 of 265 , 1680, and $2040 \mathrm{~g} \mathrm{O}_{2} \mathrm{~m}^{-2} \mathrm{yr}^{-1}$, for the UB, MB, and LB stations respectively. Values of annual production for the mesohaline region, based on ${ }^{14} \mathrm{C}$ uptake techniques, range from 350 to $850 \mathrm{~g} \mathrm{C} \mathrm{m}^{-2} \mathrm{yr}^{-1}$ (Taft et al. 1980, Boynton et al. 1982). More recently, Malone et al. $(1986,1988)$ have reported annual production estimates, for a station in the near vicinity of the present MB station, that range from 430 to $550 \mathrm{~g} \mathrm{C} \mathrm{m}^{-2} \mathrm{yr}^{-1}$. Converting our daytime net community production rate at $\mathrm{MB}$ to carbon units, assuming a photosynthetic

Table 1. Multiple linear regression analysis of net community production $\left(P_{n}\right)$ in relation to daily insolation (PAR, Ein $\mathrm{m}^{-2} \mathrm{~d}^{-1}$ ) and in situ temperature $\left(\mathrm{T},{ }^{\circ} \mathrm{C}\right)$ in Chesapeake Bay. Values for PAR taken from $\mathrm{T}$. R. Fisher (unpubl. data) and for temperature from Fig. 3

\begin{tabular}{|lcccc|}
\hline Station & Multiple regression & $\mathrm{r}^{2}$ & $\mathrm{n}$ & \\
\hline UB & $P_{\mathrm{n}}=-0.24+0.008 \mathrm{PAR}+0.045 \mathrm{~T}$ & 0.78 & 10 & $\mathrm{p}<0.01$ \\
MB & $P_{\mathrm{n}}=1.48+0.014 \mathrm{PAR}+0.169 \mathrm{~T}$ & 0.73 & 14 & $\mathrm{p}<0.01$ \\
LB & $P_{\mathrm{n}}=-1.27+0.109 \mathrm{PAR}+0.197 \mathrm{~T}$ & 0.72 & 13 & $\mathrm{p}<0.01$ \\
\hline
\end{tabular}



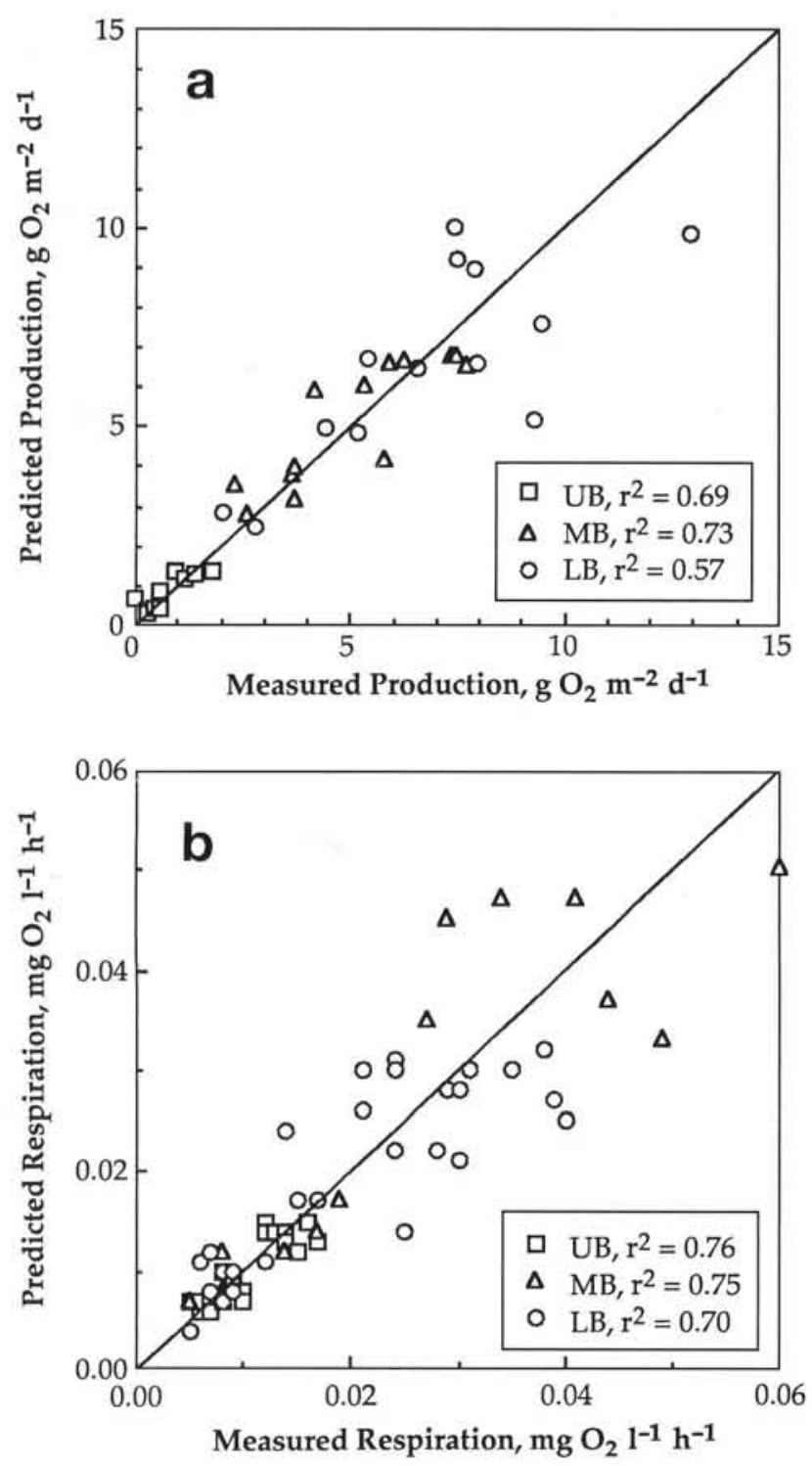

Fig. 5. Comparison of predicted and measured plankton community metabolic rates of (a) net community production $\left(\mathrm{g} \mathrm{O}_{2} \mathrm{~m}^{-2} \mathrm{~d}^{-1}\right)$, and (b) respiration $\left(\mathrm{mg} \mathrm{O}_{2} \mathrm{l}^{-1} \mathrm{~h}^{-1}\right)$. Solid line indicates 1:1 relationship; $\mathrm{r}^{2}$ values for each station given separately

quotient $\left(\mathrm{CO}_{2}: \mathrm{O}_{2}\right)$ of 1.2 , yields a value of $525 \mathrm{~g} \mathrm{C} \mathrm{m}^{-2}$ $\mathrm{yr}^{-1}$, which is towards the upper end of reported annual estimates for this region of the Bay. There is only 1 previous report of plankton production for the upper region of Chesapeake Bay (Flemer 1970). These rates $\left(200 \mathrm{~g} \mathrm{O}_{2} \mathrm{~m}^{-2} \mathrm{yr}^{-1}\right)$ are somewhat lower than those obtained in this study $\left(265 \mathrm{~g} \mathrm{O}_{2} \mathrm{~m}^{-2} \mathrm{yr}^{-1}\right)$. There are presently no published accounts in the literature regarding annually integrated production rates for the lower region of the Chesapeake Bay. Thus, the daytime net plankton community production rates reported here for LB station $\left(2040 \mathrm{~g} \mathrm{O}_{2} \mathrm{~m}^{-2} \mathrm{yr}^{-1}\right.$, or $637 \mathrm{~g} \mathrm{C} \mathrm{m}^{-2} \mathrm{yr}^{-1}$ ) represent the first annual estimate for plankton production in the polyhaline southern region of the Bay.

$\mathrm{Chl} a$ was routinely measured during the present study as an indicator of phytoplankton biomass (Fig. 6). The strongest seasonal trend in chl a occurred at MB, which peaked during the high river-flow conditions of March and April, where vertically integrated concentrations regularly exceeded $400 \mathrm{mg} \mathrm{chl} \mathrm{a} \mathrm{m} \mathrm{m}^{-2}$ for the entire water column. Phytoplankton biomass subse-

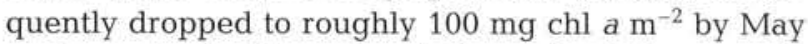
and remained at those levels throughout the year. At the LB station a similar pattern was evident, but maximal chl a values were only half those at MB. Chl a levels at LB dropped to approximately $50 \mathrm{mg} \mathrm{chl} \mathrm{a} \mathrm{m}^{-2}$

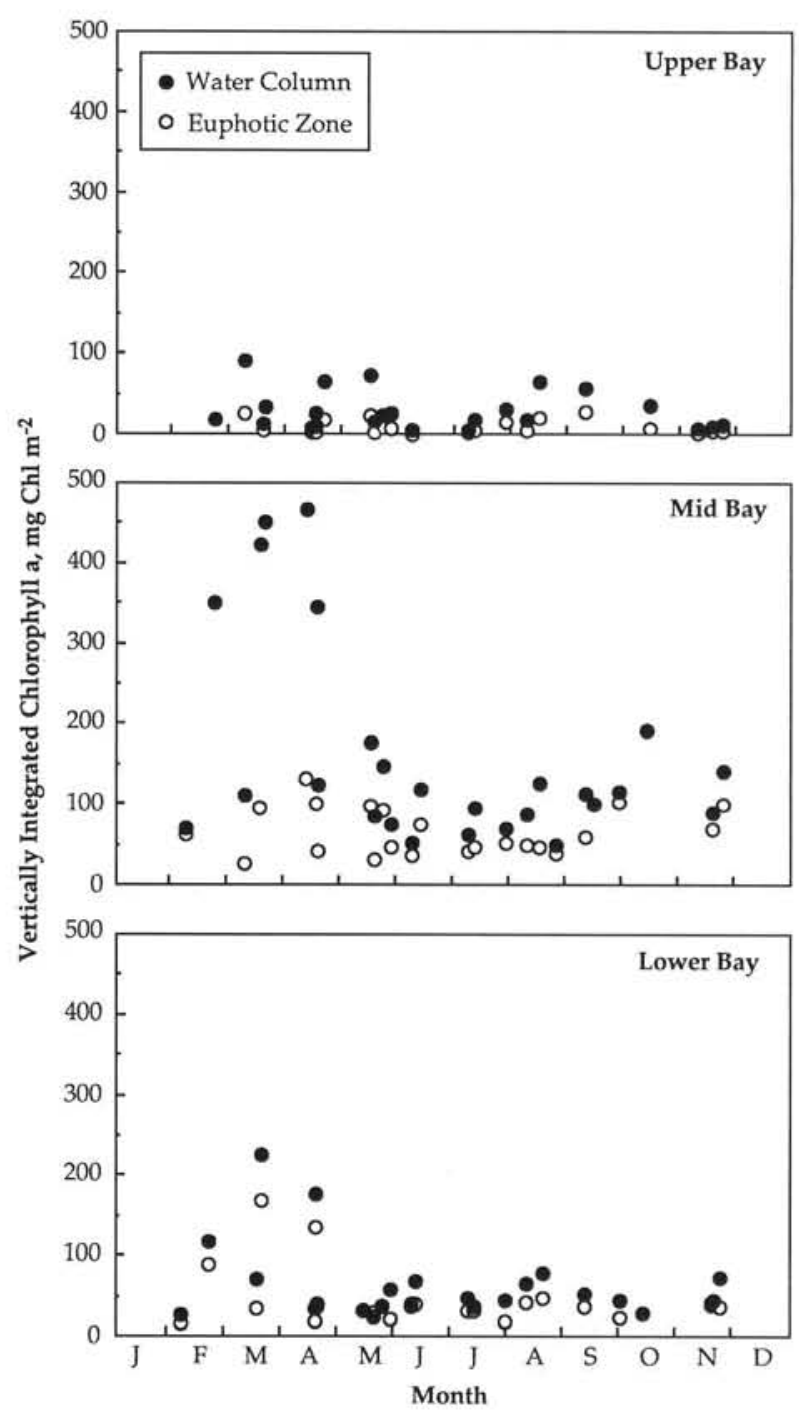

Fig. 6. Seasonal patterns (based on data for 1989 to 1991) of vertically integrated chlorophyll $a$ for both the euphotic zone and the entire water column 
for the remainder of the year The highly turbid UB, on the other hand, showed only a very weak seasonal pattern in chl a, with low biomass throughout the year, and an annual mean chl a value of only $28 \mathrm{mg}$ chl a $\mathrm{m}^{-2}$. Thus, for the MB and LB stations, plankton production rates are in fact out of phase with biomass levels, a finding also found previously by Malone et al. $(1986,1988)$ for the mesohaline region of the Bay. In their review of estuarine production, however, Boynton et al. (1982) however, found that in the majority of estuaries sampled, annual plankton production patterns paralleled those of algal biomass, as indicated by chl a.

\section{Seasonal and regional variations in respiration}

As with rates of $P_{n}$, plankton community respiration rates at each station exhibited clear seasonal patterns (Fig. 7), with peak volumetric rates occurring during summer and minimal rates during the colder months (Fig. 4). The greatest seasonal variation in respiration rates occurred in the upper layer of the MB station, which ranged from $0.005 \pm 0.002$ to $0.077 \pm 0.010 \mathrm{mg}$ $\mathrm{O}_{2} \mathrm{l}^{-1} \mathrm{~h}^{-1}$. Although upper and lower layer rates for $\mathrm{MB}$ were comparable during the colder months (November, February, March), as upper layer rates began to increase rapidly during the vernal warming, lower layer rates declined, approaching zero in the July and August periods of anoxia. As with production rates, MB respiration showed a substantial increase at the September 1991 sampling date. As was the case for production rates, the seasonal pattern in respiration at the UB station exhibited the narrowest range in rates $\left(0.003 \pm 0.001\right.$ to $\left.0.022 \pm 0.003 \mathrm{mg} \mathrm{O}_{2} \mathrm{l}^{-1} \mathrm{~h}^{-1}\right)$ of the 3 stations. Measured rates in the upper and lower layers showed no significant difference from each other throughout the year, in line with the observation of little or no distinct vertical stratification at this station, based on salinity and temperature data (Fig. 4). While, on average, rates at both $\mathrm{MB}$ and $\mathrm{LB}$ tended to be comparable, rates at LB exhibited a smaller seasonal range. Upper layer respiration rates at LB tended to exceed lower layer rates throughout the vernal warming and peaked during June and July. Lower layer water temperatures in the southern Bay, however, did not reach their maximum until August (Fig. 4). At this time, lower layer respiration rates not only were at their annual peak, but were in fact higher than surface layer rates. This pattern of peak respiration rates coinciding with annual temperature maxima has been reported for other estuaries (Lima \& Williams 1978, Turner 1978, Hopkinson 1985, Kenney et al. 1988, Hopkinson et al. 1989), as well as previously for the mesohaline region of Chesapeake Bay (Kemp et al. 1992, Sampou \& Kemp

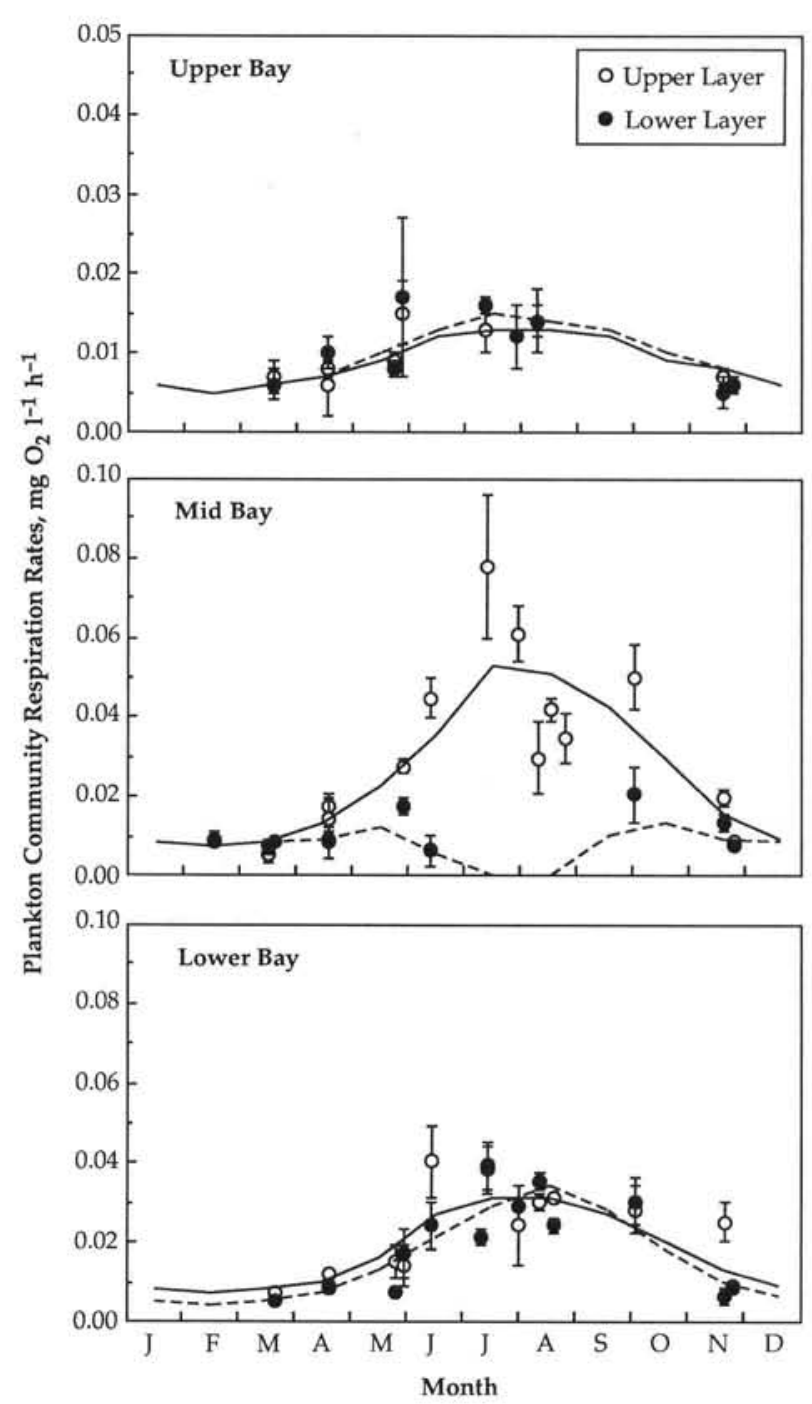

Fig. 7. Seasonal patterns (based on data for 1989 to 1991) of plankton community respiration rates (mean \pm SE) within the upper $\left(R_{\mathrm{u}}\right)$ and lower $\left(R_{\mathrm{l}}\right)$ water column at the 3 stations. Estimated monthly mean values for upper layer (solid lines) and lower layer (dashed lines) are based on exponential relationships with temperature (shown in Fig. 8)

1994). Although this same pattern has been reported for an open-water area of the Baltic (Kuparinen 1987), an exception to this seasonal trend was indicated in a Danish estuary, where peak respiration rates occurred during the spring, coincident with peak production rates (Jensen et al. 1990).

Mean measured daily volumetric respiration rates (here expressed as $\mathrm{mg} \mathrm{O}_{2} \mathrm{~m}^{-3} \mathrm{~d}^{-1}$ for comparison with other published rates) for the upper layers of both $\mathrm{MB}$ and $\mathrm{LB}$ (658 and $518 \mathrm{mg} \mathrm{O} \mathrm{m}^{-3} \mathrm{~d}^{-1}$, respectively) observed in this study are among the highest annual mean rates reported for temperate estuarine environments (Table 3 in Hopkinson 1985). Previous investiga- 
tors have reported planktonic respiration rates for the mesohaline region of Chesapeake Bay that range from approximately 200 to $1700 \mathrm{mg} \mathrm{O}_{2} \mathrm{~m}^{-3} \mathrm{~d}^{-1}$ over the course of the annual cycle (Kemp \& Boynton 1980, Taft et al. 1980, Tuttle et al. 1987, Kemp et al. 1992). Although rates from these studies are generally similar to those presented here for $\mathrm{MB}$, minimum and maximum respiration rates found in this study (120 and $1848 \mathrm{mg}$ $\mathrm{O}_{2} \mathrm{~m}^{-3} \mathrm{~d}^{-1}$ ) slightly exceed any previous reports. In contrast to the MB and LB stations, the UB station showed markedly lower annual mean respiration rates (250 $\mathrm{mg} \mathrm{O}_{2} \mathrm{~m}^{-3} \mathrm{~d}^{-1}$ ). In attempting to balance a carbon budget for this upper Bay region, taking account of the large inputs of organic matter, Biggs \& Flemer (1972) calculated (by difference) a total water column respiration of $39000 \mathrm{t} \mathrm{C} \mathrm{yr}^{-1}$, or $0.24 \mathrm{~g} \mathrm{C} \mathrm{m}^{-2} \mathrm{~d}^{-1}$. This value (assuming a RQ of 1.0: Hopkinson 1985) is roughly half the annual mean areal rate of $0.4 \pm 0.1 \mathrm{~g} \mathrm{C} \mathrm{m}^{-2} \mathrm{~d}^{-1}$ for planktonic respiration at UB measured in this study. No previous direct measures of plankton community respiration have thus far been reported in the literature for any region in the upper Chesapeake Bay. In addition, as with plankton production, no previous reports of plankton community respiration rates are available in the literature for comparison with those rates reported here for the lower polyhaline region of the Bay.

Temperature was used to generate a regressionbased model to predict the volumetric respiration rates over the annual cycle at each of the 3 stations (lines in Fig. 7). Strong relationships between plankton community respiration and temperature have been found in a number of coastal and estuarine systems (Lima \& Williams 1978, Turner 1978, Hopkinson 1985, Kuparinen 1987, Kenney et al. 1988, Howarth et al. 1992, Robinson \& Williams 1993), as well as specifically for the mesohaline region of the Chesapeake Bay (Kemp et al. 1992, Sampou \& Kemp 1994). In the present study, the relationship between plankton community respiration and temperature was better modeled as an exponential function (Fig. 8), as has been shown to be the case for many metabolic functions in plankton communities (e.g. Li \& Dickie 1987, Raven \& Geider 1988), and specifically for plankton respiration in the mesohaline region of Chesapeake Bay (Sampou \& Kemp 1994). Respiration rates were significantly $(\mathrm{p}<0.01)$ related to temperature in all instances except for $R_{1}$ at $\mathrm{MB}$, due to the seasonally anoxic nature of the lower layer at this station. Temperature (Fig. 4) was then used to predict the annual cycle of all respiration rates other than $R_{1}$ at $\mathrm{MB}$. In the latter case, a seasonal curve for bottom respiration at $M B$ was fitted to monthly means where available, and interpolated values where no monthly data were available. The precision of the model estimates for the remaining station layer respiration rates were such that $75 \%$ of all estimated rates were within $\pm 25 \%$ of observed values and $96 \%$ were with $\pm 50 \%$ of observed values (Fig. 5b). Vertically integrating these estimates and summing over the annual cycle, integrated plankton community respiration consumed on the order of 335, 1425, and $1280 \mathrm{~g} \mathrm{O}_{2} \mathrm{~m}^{-2} \mathrm{yr}^{-1}$ at the UB, MB, and LB respectively.

\section{Relationships between rates of production and respiration}

Vertically integrated plankton community respiration rates $\left(\mathrm{g} \mathrm{O}_{2} \mathrm{~m}^{-2} \mathrm{~d}^{-1}\right)$ were significantly $(\mathrm{p}<0.001)$ related (via model II regression analysis) to daytime

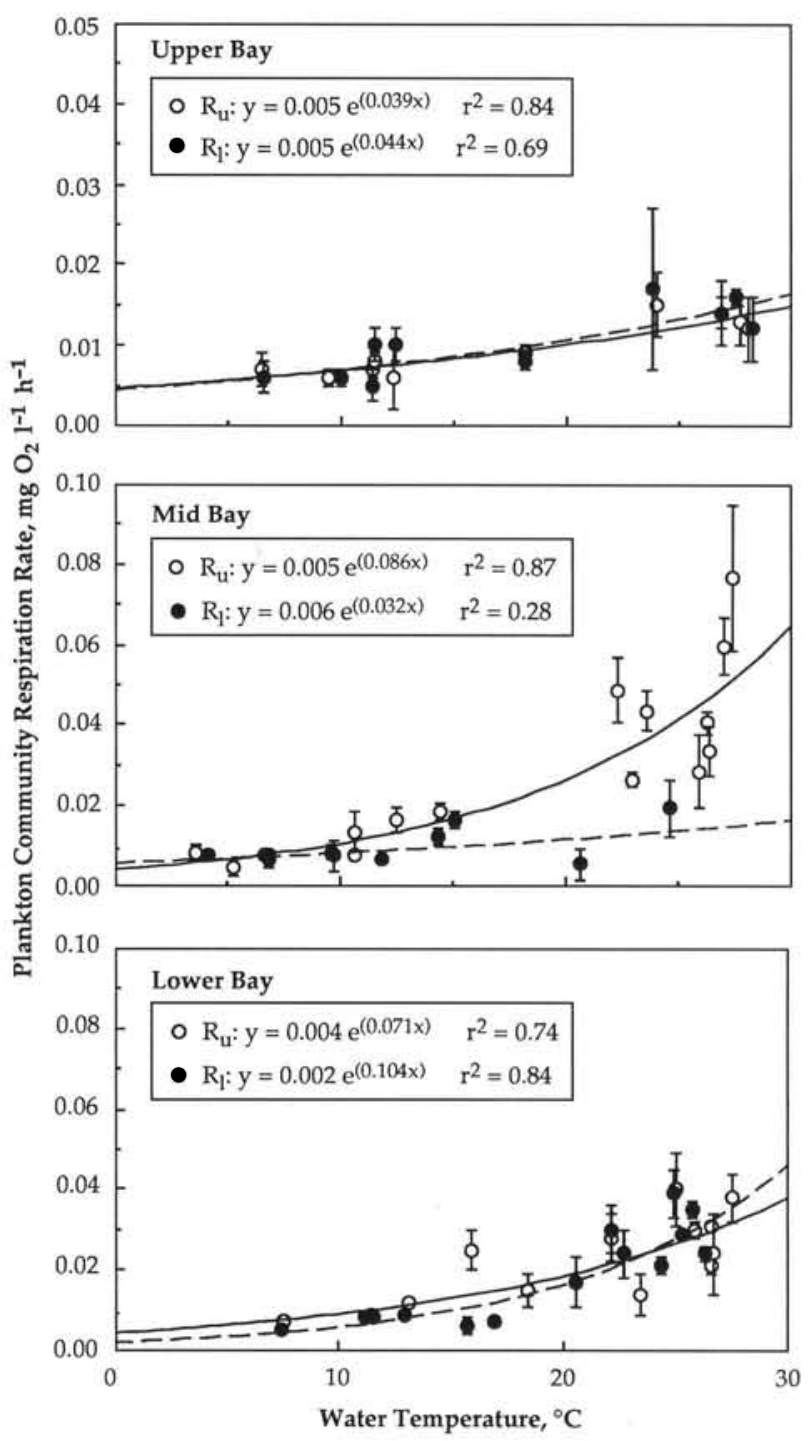

Fig. 8. Relationships between plankton community respiration rate $\left(\mathrm{mg} \mathrm{O}_{2} \mathrm{I}^{-1} \mathrm{~h}^{-1}\right)$ and in situ temperature for upper $\left(R_{\mathrm{u}}\right)$ and lower $\left(R_{1}\right)$ water column layers at the 3 stations 
net community production at the UB and MB stations, but no such relationship was seen at the LB station (Fig. 9). The slope of the regression equation for the MB station was not significantly different from unity (Student's $t$-test at $\mathrm{p}<0.01$ ) and showed little variation around the line $\left(r^{2}=0.90\right)$. This would suggest a closely balanced coupling of production and respiration at the annual scale. For the UB station, although the slope of the regression was significantly below unity $(p<0.01)$, respiration values were great enough such that respiration generally exceeded $P_{\mathrm{n}}$ and the regression line converged on the 1:1 line only at the highest rates measured. The positive $y$-intercept of the regression
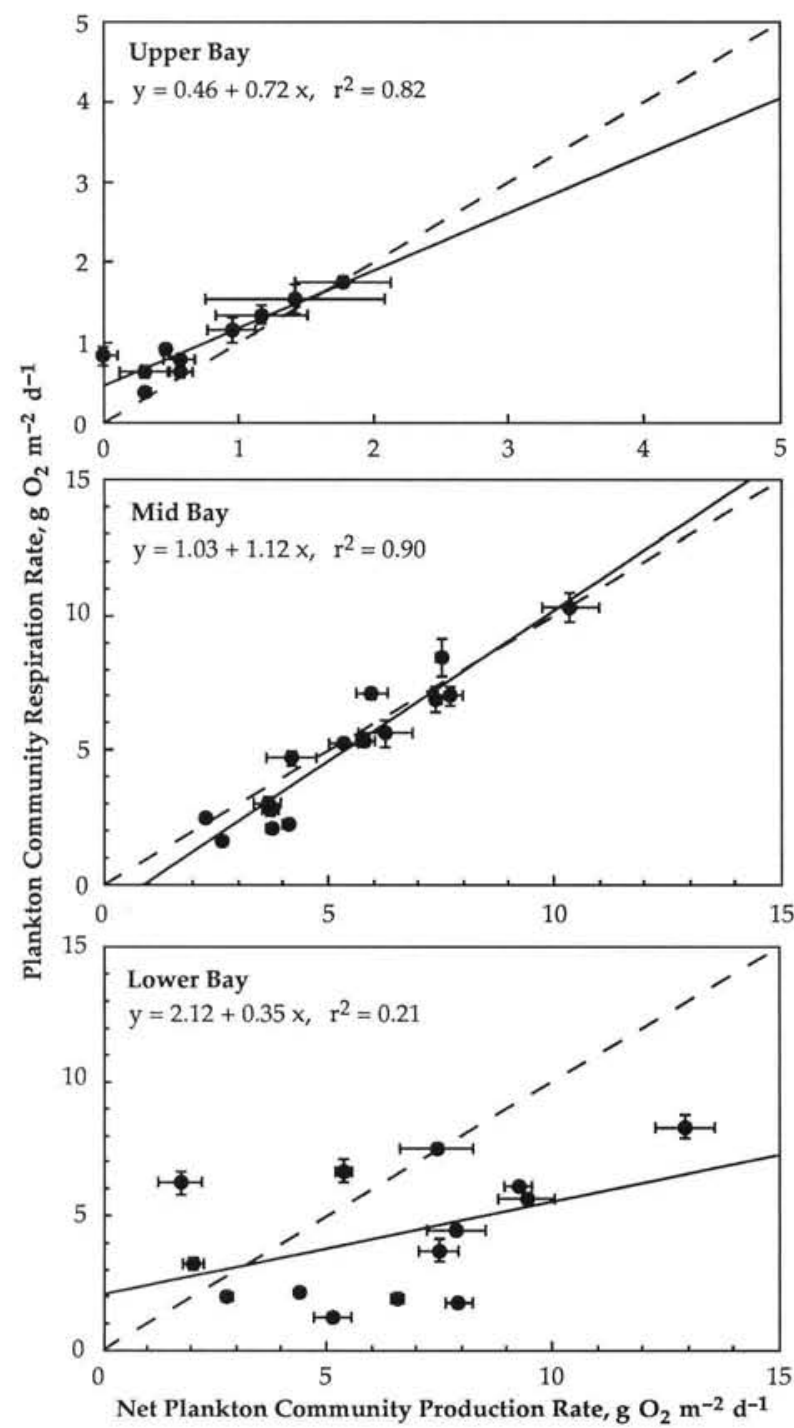

Fig. 9. Relationships between integrated plankton community respiration $\left(\mathrm{g} \mathrm{O}_{2} \mathrm{~m}^{-2} \mathrm{~d}^{-1}\right)$ and net community production $\left(\mathrm{g} \mathrm{O}_{2} \mathrm{~m}^{-2} \mathrm{~d}^{-1}\right)$ at the 3 stations. Dashed line indicates 1:1 relationship, solid line represents linear (model II) regression estimate. Error bars equal estimate of the propagated standard error for each rate was significantly different from zero $(\mathrm{p}<0.05)$, implying a background respiration rate of $0.46 \mathrm{~g} \mathrm{O}_{2} \mathrm{~m}^{-2} \mathrm{~d}^{-1}$ not associated with the in situ planktonic production. This value is equivalent to nearly half the annual mean respiration rate measured at this station. For the LB station, there was no significant ( $p<0.05$ level) slope or intercept to the relationship between production and respiration, with most of the data points lying well to the production side of the 1:1 line. This seems to suggest, then, that over the time scale of this regression, there is little or no coupling between the 2 metabolic processes within the plankton community at this station.

A close coupling between plankton production and respiration does not immediately imply causality by either variable. Heterotrophic respiration can be dependent on the supply of organic matter from contemporaneous autotrophic production. Conversely, under nutrient limited conditions, autotrophic productivity can be limited by nutrient regeneration associated with heterotrophic respiration. Although the question of control in this autotrophic-heterotrophic coupling is largely circular, differences in environmental conditions at the 2 stations suggest different causal directions. The strong correlation between production and respiration at UB suggests the responsiveness of heterotrophic metabolism to in situ phytoplankton production at this station, even with the high organic loading to this region (Biggs \& Flemer 1972). Daytime net production levels at the UB station are substantially lower than those at the other 2 stations, however, and this is also reflected in respiration rates. The high turbidity, even in the face of high nutrient loading (Schubel \& Pritchard 1986), results in $P_{\mathrm{n}}$ being lightlimited (Fisher et al. 1988, 1992). The MB station, on the other hand, is well below the turbidity maximum and has been shown to be nutrient limited throughout the year (Fisher et al. 1992). Within this region, nutrient levels are, in fact, at their lowest concentrations when rates of $P_{\mathrm{n}}$ are greatest (Malone et al. 1988). For estuaries in general, high summer productivities under low ambient inorganic nutrient concentrations has often been interpreted as an indication of the importance of temperature-dependent heterotrophic nutrient recycling in regulating primary production (Boynton et al. 1982, Kemp \& Boynton 1984, Kenney et al. 1988). The tightly balanced relationship between respiration and production seen at the MB station in the present study would then appear to be a reflection of the efficient nutrient recycling, at the annual scale, within the mesohaline region of Chesapeake Bay.

Over shorter time scales, close coupling between production and respiration was dramatically demonstrated in the September (1991) sampling date at the MB station. The timing of this sampling cruise was 
and organic matter were greatest, P:R ratios at each station deviated significantly from zero. During spring at the UB station, when turbidity and light extinction coefficients were at their highest (data not shown), levels of $P_{\mathrm{n}}$ were low. Relatively high rates of community respiration at this time, however, combined to drive $P: R$ ratios significantly below 1 . This spring period of net heterotrophic plankton community metabolism was coincident with the timing of maximum allochthonous organic input from the Susquehanna River (Biggs \& Flemer 1972). For MB and LB, the pattern was reversed. Here the plankton community metabolism was distinctly autotrophic in nature during the springtime period. $\mathrm{P}: \mathrm{R}$ ratios reached a maximum of almost 2 at $\mathrm{MB}$ and slightly over 4 at LB, although the variation at LB was much greater, possibly reflecting the uncoupled nature of production and respiration seen at this station. Evidently, for the MB and LB stations, springtime allochthonous inputs of inorganic nutrients were more important than inputs of organic matter. This, coupled with the fact that daytime net plankton production was less temperature-dependent than respiration, led to relatively high $\mathrm{P}: \mathrm{R}$ ratios in spring. The differential responses of respiration and production to temperature, however, resulted in $\mathrm{P}: \mathrm{R}$ converging on unity over the course of the vernal warming. As a result, when individual metabolic rates were at their maximal measured rates, $\mathrm{P}: \mathrm{R}$ ratios were, in fact, closest to unity (Figs. 3, $7 \& 10$ ).

It is interesting to note that the convergence of $\mathrm{P}$ and $\mathrm{R}$ appeared to occur between May and June at each station, when water temperatures were in the range of 18 to $20^{\circ} \mathrm{C}$ (Fig. 4). At least for the well-documented mesohaline region of the Bay, it is during this time that the annual transition from a spring bloom of large diatoms to a summer assemblage of smaller flagellated cells occurs (Sellner 1987, Malone et al. 1988). Also at this time, pico- and nanoplankton increase to become substantial contributors of phytoplankton primary production (McCarthy et al. 1984, Malone et al. 1991) and it appears that a large fraction of organic production is shunted through the microbial loop (Jonas \& Tuttle 1990, Malone et al. 1991, Ducklow \& Shiah 1993). At the LB station, the decline in diel plankton community metabolism to heterotrophy observed in June (Fig. 10) was followed by a modest increase during July and August (on 4 of 5 occasions during this period P:R was distinctly positive).

While the ratio $P: R$ indicates the relative degree of autotrophy or heterotrophy, the absolute amount of net organic matter production or consumption is a function of the magnitude of $\mathrm{P}$ and $\mathrm{R}$. Seasonal means for diel net plankton community metabolism have been calculated for both the upper (euphotic) layer $\left(N P M_{\mathrm{u}}\right)$ and for the entire water column (NPM) at the 3 stations (Table 2). $N P M_{\mathrm{u}}$ was net autotrophic in all cases except in the spring at UB and fall at LB, when $P_{n}$ levels were markedly lower, and was thus capable of supplying in situ organic matter to fuel lower layer heterotrophic consumption at each station. Highest rates of $N P M_{u}$ occurred at the LB station during summer and averaged roughly $7.0 \mathrm{~g} \mathrm{O}_{2} \mathrm{~m}^{-2} \mathrm{~d}^{-1}$. The longitudinal progression in springtime plankton $\mathrm{P}: \mathrm{R}$ ratios discussed above can clearly be seen in mean NPM values as going from a net consumption of $-0.40 \mathrm{~g} \mathrm{O}_{2} \mathrm{~m}^{-2} \mathrm{~d}^{-1}$ at UB to a net production of $1.05 \mathrm{~g} \mathrm{O}_{2} \mathrm{~m}^{-2} \mathrm{~d}^{-1}$ at $\mathrm{MB}$ and $4.15 \mathrm{~g} \mathrm{O}_{2} \mathrm{~m}^{-2} \mathrm{~d}^{-1}$ at LB. As water column P:R ratios approached unity in warmer seasons, $N P M$ was zero during summer and fall at both $\mathrm{UB}$ and $\mathrm{MB}$; at the LB station, however, NPM was positive, reaching almost $3.0 \mathrm{~g} \mathrm{O}_{2} \mathrm{~m}^{-2} \mathrm{~d}^{-1}$.

It appears that the negative $N P M$ value of $-0.40 \mathrm{~g} \mathrm{O}_{2}$ $\mathrm{m}^{-2} \mathrm{~d}^{-1}$ at the UB station during spring reflects a substantial subsidy of allochthonous organic inputs to the plankton community. Because mean in situ rates of $P_{\mathrm{n}}$ at this time were only $0.55 \mathrm{~g} \mathrm{O}_{2} \mathrm{~m}^{-2} \mathrm{~d}^{-1}$, plankton community respiration was dependent on an additional external source of organic matter equivalent to some $70 \% P_{\mathrm{n}}$. A reasonable alternative source of organic matter supporting this net heterotrophy at the UB station would be that transported by the Susquehanna River. The average mean delivery rate of total organic carbon for the period of March to May, over an $11 \mathrm{yr}$ record from 1978 to 1988 , was $6.7 \times 10^{5} \mathrm{~kg} \mathrm{C} \mathrm{d}^{-1}$ (B. Summers unpubl. data). Assuming this load is evenly distributed over the upper Bay area from the Susque-

Table 2. Seasonal mean values for net plankton community metabolism $\left(\mathrm{g} \mathrm{O}_{2} \mathrm{~m}^{-2} \mathrm{~d}^{-1}\right)$ for the upper layer (NPM $\left.M_{\mathrm{u}}\right)$ and entire water column (NPM) of Chesapeake Bay during winter-spring (January-May), summer (July-August), and Fall (September-December). Zero values indicate rates not significantly different (at the $\mathrm{p}>0.05$ level) from balanced metabolism. Values in parentheses are standard errors of the means

\begin{tabular}{|c|c|c|c|c|c|c|}
\hline \multirow[t]{2}{*}{ Season } & \multicolumn{2}{|c|}{ Upper Bay } & \multicolumn{2}{|c|}{ Mid Bay } & \multicolumn{2}{|c|}{ Lower Bay } \\
\hline & $N P M_{\mathrm{u}}$ & $N P M$ & $N P M_{\mathrm{u}}$ & $N P M$ & $N P M_{\mathrm{u}}$ & $N P M$ \\
\hline Winter-spring & 0 & $-0.4(0.2)$ & $2.1(0.4)$ & $1.1(0.4)$ & $5.7(1.5)$ & $4.2(1.4)$ \\
\hline Summer & $0.7(0.2)$ & 0 & $2.4(1.2)$ & 0 & $7.0(2.0)$ & $3.0(1.8)$ \\
\hline Fall & $0.2(0.1)$ & 0 & $1.9(1.0)$ & 0 & 0 & 0 \\
\hline
\end{tabular}


\& Flemer 1972) and published hypsographic data (Cronin \& Pritchard 1975) we were able to estimate the bay wide mean rate of diel net plankton community metabolism. While the overall (plankton plus benthic) organic balance has yet to be quantified for Chesapeake Bay, it is clear that the plankton community within the main-stem Bay is strongly autotrophic in nature, despite respiration rates that were among the highest recorded for aquatic systems. On a mean bay-wide level the positive net plankton production (494 $\mathrm{g} \mathrm{O}_{2} \mathrm{~m}^{-2} \mathrm{yr}^{-1}$; $185 \mathrm{~g} \mathrm{C} \mathrm{m}^{-2} \mathrm{yr}^{-1}$ assuming $\mathrm{PQ}=$ $R Q=1.0$ ) represents a substantial source of organic matter available for export to the benthos, to higher pelagic trophic levels, or to the adjacent coastal ecosystem.

Acknowledgements. This study was supported in part by the NOAA, Maryland Sea Grant College (R/P-32) and NSF LMER Program (No. BSR-8814272). We acknowledge contributions of W. Boicourt, W. Boynton, J. Cornwell and T. Malone in their reviews of an earlier version of this manuscript, as well as the contributions of anonymous reviewers. We are indebted to Lisa Rossman who help collect field data, and to Steve Kelly and Sherry Pike for chlorophyll a data. We thank T. R. Fisher for use of unpublished light data. Linda May and Lee May were generous in assisting with both SAS applications and error analyses, particularly in differentiating the error-propagation equation. We also express thanks to the captains and crew of the RV 'Warfield', 'Cape Hatteras', and especially the 'Cape Henlopen'.

\section{LITERATURE CITED}

Bender, M. L., Grande, K. D. (1987). Production, respiration, and the isotope geochemistry of oxygen in the upper water column. Global biogeochem. Cycles 1: 49-59

Bevington, P. R. (1969). Data reduction and error analysis for the physical sciences. McGraw-Hill, New York

Biggs, R. B., Flemer, D. A. (1972). The flux of particulate carbon in an estuary. Mar. Biol. 12: 11-17

Boynton, W. R., Garber, J. H., Summers, R., Kemp, W. M. (1994). Inputs, transformations and transport of nitrogen and phosphorus in Chesapeake Bay and selected tributaries. Estuaries (in press)

Boynton, W. R., Kemp, W. M., Keefe, C. W. (1982). A comparative analysis of nutrients and other factors influencing estuarine phytoplankton production. In: Kennedy, V. (ed.) Estuarine comparisons. Academic Press, New York, p. $67-90$

Carritt, D. E., Carpenter, J. H. (1966). Comparison and evaluation of currently employed modifications of the Winkler method for determining dissolved oxygen in seawater; a NASCO report. J. mar. Res. 24: 286-319

Cowan, J. L. W., Boynton, W. R. (1994). Sediment-water oxygen and nutrient exchanges along the longitudinal axis of Chesapeake Bay. Estuaries (in press)

Cronin, W. B., Pritchard, D. W. (1975). Additional statistics on the dimensions of the Chesapeake Bay and its tributaries: cross-sectional widths and segment volumes per meter depth. Ches. Bay Inst. Spec. Rep. 42

Ducklow, H. W., Shiah, F. (1993). Bacterial production in estuaries. In: Ford, T. (ed.) Aquatic microbiology: an ecological approach. Blackwell Scientific, New York, p. 261-288

Fisher, T. R., Harding, L. W., Stanley, D. W., Ward, L. G. (1988). Phytoplankton, nutrients, and turbidity in the Chesapeake, Delaware, and Hudson estuaries. Estuar. coast. Shelf Sci. 27: 61-93

Fisher, T. R., Peele, E. R., Ammerman, J. W., Harding, L. W. (1992). Nutrient limitation of phytoplankton in Chesapeake Bay. Mar. Ecol. Prog. Ser. 82: 51-63

Flemer, D. A. (1970). Primary production in Chesapeake Bay. Chesapeake Sci. 11: 117-129

Gaarder, T., Gran, H. H. (1927). Investigation of the production of plankton in the Oslo Fjord. Rapp. P.-v. Cons. int. Explor. Mer 42: 1-48

Geider, R. J. (1992). Respiration: taxation without representation. In: Falkowski, P. G., Woodhead, A. D. (eds.) Primary productivity and biogeochemical cycles in the sea. Plenum Press, New York, p. 333-360

Goodrich, D. M., Boicourt, W. C., Hamilton, P., Pritchard, D. W. (1987). Wind-induced destratification in Chesapeake Bay. J. phys. Oceanogr. 17: 2232-2240

Griffith, P. C. (1988). A high-precision respirometer for measuring small rates of change in the oxygen concentration of natural waters. Limnol. Oceanogr. 33: 632-638

Harding, L. W., Messon, B. W., Fisher, T. R. (1986). Phytoplankton production in two east coast estuaries: photosynthesis-light functions and patterns of carbon assimilation in Chesapeake and Delaware Bays. Estuar. coast. Shelf Sci. 23: 773-806

Hartwig, E. O., Michael, J. A. (1978). A sensitive photoelectric Winkler titrator for respiration measurements. Environ. Sci. Technol. 12: 712-715

Hopkinson, C. S. (1985). Shallow-water benthic and pelagic metabolism: evidence of heterotrophy in the nearshore Georgia Bight. Mar. Biol. 87: 19-32

Hopkinson, C. S., Sherr, B., Wiebe, W. J. (1989). Size fractionated metabolism of coastal microbial plankton. Mar. Ecol. Prog. Ser. 51: 155-166

Hoppema, J. M. (1991). The oxygen budget of the western Wadden Sea, The Netherlands. Estuar. Coast. Shelf Sci. 32: $483-502$

Howarth, R. W., Marino, R., Garret, R., Sherman, D. (1992). Ecosystem respiration and organic carbon processing in a large, tidally influenced river: the Hudson River. Biogeochemistry 16: 83-102

Iverson, R. L. (1990). Control of marine fish production. Limnol. Oceanogr. 35: 1593-1604

Jassby, A. D., Platt, T. (1976). Mathematical formulation of the relationship between photosynthesis and light for phytoplankton. Limnol. Oceanogr. 21: 540-547

Jensen, L. M., Sand-Jenson, K., Marcher, S., Hansen, M. (1990). Plankton community respiration along a nutrient gradient in a shallow Danish estuary. Mar. Ecol. Prog. Ser. 61: $75-85$

Jonas, R. B., Tuttle, J. H. (1990). Bacterioplankton and organic carbon dynamics in the lower mesohaline Chesapeake Bay. Appl, environ. Microbiol. 56: 747-757

Kana, T. M. (1990). Light-dependent oxygen cycling measured by an oxygen-18 isotope dilution technique. Mar. Ecol. Prog. Ser. 64: 293-300

Kemp, W. M., Boynton, W. R. (1980). Influence of biological and physical factors on dissolved oxygen dynamics in an estuarine system: implications for measurement of community metabolism. Estuar. coast. mar. Sci. 11: 407-431

Kemp, W. M., Boynton, W. R. (1984). Spatial and temporal coupling of nutrient inputs to primary production: the role of particulate transport and decomposition. Bull. mar. Sci. 35: $522-535$ 
Kemp, W. M., Sampou, P. A., Garber, J., Tuttle, J., Boynton, W. R. (1992). Seasonal depletion of oxygen from bottom waters of Chesapeake Bay: roles of benthic and planktonic respiration and physical exchange processes. Mar. Ecol. Prog. Ser. 85: 137-152

Kenney, B. E., Litaker, W., Duke, C. S., Ramus, J. (1988). Community oxygen metabolism in a shallow tidal estuary. Estuar. coast. Shelf Sci. 27: 33-43

Kuparinen, J. (1987). Production and respiration of overall plankton and ultraplankton communities at the entrance to the Gulf of Finland in the Baltic Sea. Mar. Biol. 93: 591-607

Langdon, C. (1984). Dissolved oxygen monitoring system using a pulsed electrode: design, performance and evaluation. Deep Sea Res. 31: 1357-1367

Li, W. K. W., Dickie, P. M. (1987). Temperature characteristics of photosynthetic and heterotrophic activities: seasonal variations in temperate microbial plankton. Appl. environ. Microbiol, 53: 2282-2295

Lima, H. d. S., Williams, P. J. LeB. (1978). Oxygen consumption by the planktonic population of an estuary Southampton Water. Estuar. coast. mar. Sci. 6: 515-521

Malone, T. C., Crocker, L. H., Pike, S. E., Wendler, B. W. (1988). Influences of river flow on the dynamics of phytoplankton production in a partially stratified estuary. Mar. Ecol. Prog. Ser. 48: 235-249

Malone, T. C., Ducklow, H. W., Peele, E. R., Pike, S. E. (1991). Picoplankton carbon flux in Chesapeake Bay. Mar. Ecol. Prog. Ser, 78: 11-22

Malone, T. C., Kemp, W. M., Ducklow, H. W., Boynton, W. R., Tuttle, J. H., Jonas, R. B. (1986). Lateral variation in the production and fate of phytoplankton in a partially stratified estuary. Mar. Ecol. Prog. Ser. 32: 149-160

Marquardt, D. W. (1963). An algorithm for least squares estimation of nonlinear parameters. J. Soc. Ind. Appl. Math. 11: $431-441$

Mayer, M. S. (1992). Effects of benthic macrofauna on nitrogen cycling and oxygen consumption of estuarine sediments. Ph.D. thesis, University of Maryland, College Park

McCarthy, J. J., Kaplan, W., Nevins, J. L. (1984). Chesapeake Bay nutrients and phytoplankton dynamics. 2. Sources and sinks of $\mathrm{NO}_{2}^{-}$. Limnol. Oceanogr. 29: 84-98

Nixon, S. W., Oviatt, C. A., Frithsen, J., Sullivan, B. (1986). Nutrients and the productivity of estuarine and coastal marine ecosystems. J. Limnol. Soc. S. Afr. 12: 43-71

Nixon, S. W., Pilson, M. E. Q. (1984). Estuarine total system metabolism and organic exchange calculated from nutrient ratios: an example from Narragansett Bay. In: Kennedy, V. S. (ed.) The estuary as a filter. Academic Press, New York, p. 261-290

Odum, H. T. (1956). Primary production in flowing waters. Limnol. Oceanogr. 1: 102-117

Oudot, C., Gerard, R., Morin, P. (1988). Precise shipboard determination of dissolved oxygen (Winkler procedure) for productivity studies with a commercial system. Limnol. Oceanogr. 33: 146-150

Parsons, T. R., Maita, Y., Lalli, C. (1984). A manual of chemi$\mathrm{cal}$ and biological methods for seawater analysis. Pergamon Press, Oxford

Peterson, B. J. (1980). Aquatic primary productivity and the ${ }^{14} \mathrm{C}-\mathrm{CO}_{2}$ method: a history of the productivity problem. A. Rev. Ecol. Syst. 11: 359-385
Raven, J. A., Geider, R. J. (1988). Temperature and algal growth. New Phytol. 110: 441-461

Robinson, C., Williams, P. J. L. (1993). Temperature and arctic plankton community respiration. J. Plankton Res. 15: 1035-1052

Ryther, J. H. (1954). The ecology of phytoplankton blooms in Moriches Bay and Great South Bay, Long Island, New York. Biol. Bull. 106: 198-209

Sampou, P., Kemp, W. M. (1994). Factors regulating plankton community respiration in Chesapeake Bay. Mar. Ecol. Prog. Ser. 110: 249-258

Schubel, J. R., Pritchard, D. W. (1986). Responses of upper Chesapeake Bay to variations in discharge of the Susquehanna River. Estuaries 9: 236-249

Sellner, K. (1987). Phytoplankton in Chesapeake Bay: role in carbon, oxygen and nutrient dynamics. In: Majumdar, S. K., Hall, J. L. W., Austin, H. M. (eds.) Contaminant problems and management of living Chesapeake Bay resources. The Pennsylvania Academy of Science, Easton, p. $134-157$

Smith, S. V. (1991). Stoichiometry of C:N:P fluxes in shallowwater marine ecosystems. In: Cole, J., Lovett, G., Findlay, S. (eds.) Comparative analyses of ecosystems. Patterns, mechanisms, and theories. Springer-Verlag, New York, p. 259-286

Smith, S. V., Mackenzie, F. T. (1987). The ocean as a net heterotrophic system: Implications from the carbon biogeochemical cycle. Global biogeochem. Cycles 1: $187-198$

Steemann-Nielsen, E. (1952). The use of radioactive carbon $(14 \mathrm{C})$ for measuring organic production in the sea. J. Cons, int. Explor. Mer 18: 117-140

Taft, J. L., Taylor, W. R., Hartwig, E. O., Loftus, R. (1980). Seasonal oxygen depletion in Chesapeake Bay. Estuaries 3: 242-247

Turner, R. E. (1978). Community plankton respiration in a salt marsh estuary and the importance of macrophytic leachates. Limnol. Oceanogr. 23: 442-451

Tuttle, J. H., Jonas, R. R., Malone, T. C. (1987). Origin, development and significance of Chesapeake Bay anoxia. In: Majumdar, S. K., Hall, L. W., Austin, H. M. (eds.) Contaminant problems and management of living Chesapeake Bay Resources. The Pennsylvania Academy of Science, Easton, p. 442-472

Tyler, M. A., Seliger, H. H. (1978). Annual subsurface transport of a red tide dinoflagellate to its bloom area: water circulation patterns and organism distributions in the Chesapeake Bay. Limnol. Oceanogr. 23: 227-246

Van Es, F. B. (1982). Community metabolism of intertidal flats in the Ems-Dollard estuary. Mar. Biol. 66: 95-108

Williams, P. J. LeB. (1984). A review of measurements of respiration rates of marine plankton populations. In: Hobbie, J. E., Williams, P. J. LeB. (eds.) Heterotrophic activity in the sea. Plenum Press, New York, p. 357-389

Williams, P. J. LeB., Jenkinson, N. W. (1982). A transportable microprocessor-controlled precise Winkler titration suitable for field stations and shipboard use. Limnol. Oceanogr. 27: 576-584

Wofsy, S. C. (1983). A simple model to predict extinction coefficients and phytoplankton biomass in eutrophic waters. Limnol. Oceanogr. 28: 1144-1155

Manuscript first received: March 14, 1994

Revised version accepted: September 30, 1994 